\title{
Pulsed Field Gel Electrophoresis of group A streptococci
}

Vitali Luca Agostino ${ }^{1 *}$, Gherardi Giovanni ${ }^{2}$, Petrelli Dezemona ${ }^{3}$

${ }^{1}$ School of Pharmacy, University of Camerino. Camerino (MC), Italy

${ }^{2}$ University "Campus Bio-Medico", Rome

${ }^{3}$ School of Biosciences and Veterinary Medicine, University of Camerino, Camerino (MC), Italy

Running head: "PFGE of Streptococcus pyogenes"

*Corresponding author:

Phone: +39-0737-403282

e-mail: luca.vitali@unicam.it 


\section{Summary}

Here we describe the protocols to perform PFGE analysis of chromosomal DNA from the bacterial species Streptococcus pyogenes (group A streptococcus, GAS) after digestion with the restriction enzyme SmaI. Large parts of the procedures are suitable for application to DNA digested with other restriction enzymes as well. We have put an effort to present extensions to solve possible limitations to the discriminatory power of the method in the specific case of $S$. pyogenes.

Key Words: Streptococcus pyogenes, group A streptococcus, GAS, PFGE, SmaI, chromosomal DNA, macrorestriction. 


\section{Introduction}

Pulsed-field gel electrophoresis (PFGE) of chromosomal DNA extracted from Streptococcus pyogenes is a molecular typing method considered among the 'gold standard' tools used to investigate the clonal relationships between clinical Group A streptococci (GAS) isolates during an epidemic survey or to study outbreaks. This technique is also considered useful and suitable in large studies aimed at investigating the global clonal expansion and evolution of this human pathogen. Several studies have reported the use of PFGE, but none of them have addressed the methodological issues of the technique in the sole and specific case of $S$. pyogenes. This chapter is mainly aimed at filling this gap. Actually, the use of PFGE for $S$. pyogenes typing, albeit extensively applied, has not gained the same significance as the method has in the case of the study of other important human pathogens like Staphylococcus aureus. As for the latter organism, the worldwide spread of major staphylococcal clones has given the opportunity of exploiting PFGE to follow its diffusion $(1,2)$.

Nevertheless, macrorestriction profiling by PFGE of $S$. pyogenes has shown a high degree of correlation with other typing methods. This is the case of emm-typing, which is the determination of the 5 '-end sequence of the gene coding for the major virulence factor $\mathrm{M}$ protein. The method consists of a classification scheme comprising more than 200 variants. Several molecular epidemiology studies have demonstrated a good level of correlation between emm-typing and PFGE analysis by using $S m a I$ restriction enzyme to digest genomic DNA $(3,4,5)$. Moreover, other traits used to characterize GAS clinical strains have been found to correlate well with PFGE, such as MLST and, even at a lower degree, genetic determinants 
of erythromycin resistance (4). In addition, the virulence genes' content also correlates well with PFGE clustering analysis (6). This may be due to the fact that several virulence genes are carried by large genetic mobile elements, such as prophages, which, due to their average number per genome and size, greatly influence the physical structure of the genome (7).

PFGE is a simple but powerful technique to assess inter- and intra-species bacterial diversity. It is based on the separation of large fragments of DNA, resulting from the specific endonucleolytic activity of rare cutting restriction enzymes on the bacterial genome or large plasmids. Basically, differences among strains depend on the presence/absence of the specific restriction endonuclease recognition sites and distance separating restriction sites.

Comparisons of electrophoretic banding patterns allow determination of the relatedness of the corresponding genomic DNAs. A correlation degree might also be computed depending on the number of differences between patterns (8). Collected data can then be used to generate correlation trees based on UPMGA (Unweighted Pair Group Method with Arithmetic Mean). 


\section{Materials}

Prepare all solutions using ultrapure water (prepared by purifying deionized water to attain a sensitivity of $18 \mathrm{M} \Omega \mathrm{cm}$ at $25^{\circ} \mathrm{C}$ ) and analytical grade reagents. Follow all waste disposal regulations when disposing of waste materials.

\subsection{Equipments and general materials}

heating stirrer

water bath

spectrophotometer

pH-meter

incubator

vortex

multivolumentric pipettes

disposable plug molds

PFGE chamber and comb

PFGE apparatus

Todd Hewitt broth

Columbia agar plates $(+5 \%$ sheep blood $)$

SmaI and 10X Restriction buffer

CHEF DNA size standard lambda ladder

Ethidium bromide stock solution $(10 \mathrm{mg} / \mathrm{mL})$

\subsection{Preparation of agarose-embedded chromosomal DNA and restriction enzyme digestion.}


1. Low melting agarose solution (1.6\%): add $0.160 \mathrm{~g}$ of low melting agarose to $10 \mathrm{~mL}$ of water in a flask, close with a cap or aluminium foil and bring to the boil using a heating stirrer avoiding over-heating. Transfer the flask into a water bath at $50-55^{\circ} \mathrm{C}$.

2. TEN buffer: $10 \mathrm{mM}$ Tris-HCl pH8.0, $1 \mathrm{M} \mathrm{NaCl}, 10 \mathrm{mM}$ EDTA $\mathrm{pH}$ 8.0. To prepare $1 \mathrm{~L}$, in a beaker containing $500 \mathrm{~mL}$ water, mix $10 \mathrm{~mL}$ of $1 \mathrm{M}$ Tris- $\mathrm{HCl} \mathrm{pH} 7.5,58.4 \mathrm{~g} \mathrm{NaCl}, 20$ $\mathrm{mL}$ of $0.5 \mathrm{M}$ EDTA $\mathrm{pH}$ 8.0. Dissolve completely the salt and make up to $1 \mathrm{~L}$ with water. Store atroom temperature $\left(20-25^{\circ} \mathrm{C}\right)$. This solution may be prepared ahead of time. It is stable for up to 1 year.

3. Lysis solution (EC): $6 \mathrm{mM}$ Tris $\mathrm{pH}$ 7.6, $1 \mathrm{M} \mathrm{NaCl}, 100 \mathrm{mM}$ EDTA, 0.2\% sodiumdeoxycholate, $0.5 \%$ sodium lauroylsarcosine, $0.5 \%$ Brij 58 in water. To prepare $1 \mathrm{~L}$, mix in a beaker containing $500 \mathrm{~mL}$ water, $6 \mathrm{~mL}$ of $1 \mathrm{M}$ Tris- $\mathrm{HCl} \mathrm{pH} 7.6,58.4 \mathrm{~g} \mathrm{NaCl}, 200 \mathrm{~mL}$ of 0.5M EDTA pH8.0, 2 g sodium-deoxycholate, 5 g sodium lauroylsarcosine, 5 g Brij 58. Dissolve completely the salts and make up to $1 \mathrm{~L}$ with water. Store at room temperature $\left(20-25^{\circ} \mathrm{C}\right)$. This solution may be prepared ahead of time. It is stable for up to 1 year. Before use check the bottom of the storing vessel for possible precipitation of detergent. If a precipitate is present, the solution can be heated up to $40^{\circ} \mathrm{C}$ until complete dissolution. Immediately prior to use add $1 \mathrm{mg} / \mathrm{mL}$ lysozyme and $50 \mu \mathrm{g} / \mathrm{mL}$ RNase A.

4. Digestion solution (ES): 0.5 M EDTA pH 8.0, $1 \%$ sodium lauroyl-sarcosine in water. Mix $186 \mathrm{~g}$ EDTA and $700 \mathrm{~mL}$ of water and adjust to $\mathrm{pH} 8.0$ with $10 \mathrm{~N} \mathrm{NaOH}$. Add $10 \mathrm{~g}$ sodium lauroylsarcosine and make up to $1 \mathrm{~L}$ with water. Store at room temperature $\left(20-25^{\circ} \mathrm{C}\right)$. This solution may be prepared ahead of time It is stable for up to 1 year. Before use check the bottom of the storing vessel for possible precipitation of detergent. If a precipitate is present, the solution can be heated up to $40^{\circ} \mathrm{C}$ until complete dissolution. 
Immediately prior to use add $0.5 \mathrm{mg} / \mathrm{mL}$ proteinase $\mathrm{K}$.

5. TE: $10 \mathrm{mM}$ Tris $\mathrm{pH} 8.0,1 \mathrm{mM}$ EDTA $\mathrm{pH} 8.0$ in water. To prepare $1 \mathrm{~L}$ by mixing in a cylinder $10 \mathrm{~mL}$ of $1 \mathrm{M}$ Tris $\mathrm{pH} 8.0,2 \mathrm{~mL}$ of $0.5 \mathrm{M}$ EDTA $\mathrm{pH} 8.0$ and adjusting the volume to $1 \mathrm{~L}$ with water.

\subsection{Preparation of gel and electrophoretic run.}

1. 10xTBE: 1.3 M TRIS, $450 \mathrm{mM}$ boric acid and $25 \mathrm{mM}$ EDTA in water. Weigh $157.48 \mathrm{~g}$ Tris base, $27.82 \mathrm{~g}$ boric acid, $9.3 \mathrm{~g}$ EDTA and dissolve in $500 \mathrm{~mL}$ water. Finally adjust the volume to $1 \mathrm{~L}$ with water. Check the $\mathrm{pH}$ : it should be 8.3 without requiring adjustment. Store at room temperature $\left(20-25^{\circ} \mathrm{C}\right)$ Dilute 20 times with water (final concentration: $0.5 \mathrm{x}$ ) prior to use.

2. $1 \%$ agarose gel. To prepare $100 \mathrm{~mL}$ of $1.0 \%$ agarose gel: add $1 \mathrm{~g}$ of agarose to $100 \mathrm{~mL}$ of $0.5 \mathrm{x}$ TBE in a flask, close with a cap or aluminium foil and bring to boil using a heating stirrer avoiding over-heating. Before pouring, cool to $45-50^{\circ} \mathrm{C}$ under stirring. 


\section{Methods}

\subsection{Preparation of high molecular weight DNA}

The following protocol describes the procedure for a single strain. All the microbiological procedures are performed in sterile conditions.

1. Streak the selected $S$. pyogenes strain on blood agar plate and incubate at $37^{\circ} \mathrm{C}$ with $5 \%$ $\mathrm{CO}_{2}$ for 18-24 h. Transfer 3-5 colonies from the agar plate into $5 \mathrm{~mL}$ of sterile ToddHewitt broth and grow them overnight at $37^{\circ} \mathrm{C}$ with $5 \% \mathrm{CO}_{2}$. After growth, check the optical density (wavelength: $600 \mathrm{~nm}$ ) of the bacterial suspension (see Note 1).

2. Prepare $0.5 \mathrm{~mL}$ of low melting agarose per sample (see Note 2) and keep it in a water bath at $55^{\circ} \mathrm{C}$.

3. Centrifuge a suitable volume of overnight bacterial suspension containing $1-2 \times 10^{9}$ cells at $10,000 \times \mathrm{g}$ for $3 \mathrm{~min}$ (see Note 3). Discard the supernatant and resuspend the pellet in $1 \mathrm{~mL}$ of TEN buffer (see Note 4). Centrifuge again for 2-3 min at 10,000×g, discard the supernatant and resuspend the pellet in $0.5 \mathrm{~mL}$ of TEN buffer.

4. Add $0.5 \mathrm{~mL}$ of the low-melting agarose prepared at point 3.1.2. Vortex immediately for a few seconds and distribute $100 \mu \mathrm{L}$ into each well of the disposable plug mold strip (see Note 5). Let it solidify at $4^{\circ} \mathrm{C}$ for $15 \mathrm{~min}$.

5. Remove the tape present at the bottom of the plug mold strip. Push the plugs out from the mold by using a spatula and put them into a $15 \mathrm{~mL}$ sterile tube containing $2 \mathrm{~mL}$ of lysis solution (EC). Incubate at $37^{\circ} \mathrm{C}$ for $16 \mathrm{~h}$. Pour off the lysis solution paying attention not to lose the plugs. 
6. Add $3 \mathrm{~mL}$ of digestion buffer (ES + proteinase $\mathrm{K}$ ) to the plugs. Incubate for 2 days at $50^{\circ} \mathrm{C}$. Remove the buffer and add $3 \mathrm{~mL}$ of fresh ES (without proteinase $\mathrm{K}$ ). Plugs can be stored at $4^{\circ} \mathrm{C}$ for more than one year without loss of DNA integrity.

\subsection{Digestion with $S m a I$ restriction enzyme}

1. Take one plug using a spatula and submit it to an overnight dialysis with $20 \mathrm{~mL}$ of TE buffer in a $50 \mathrm{~mL}$ tube at room temperature $\left(20-25^{\circ} \mathrm{C}\right)$. Change the TE buffer every $3 \mathrm{~h}$ for 3 times the following day.

2. Digest the plug-embedded DNA in $0.3 \mathrm{~mL}$ solution containing $1 \mathrm{X}$ restriction buffer and 20 $\mathrm{U}$ of SmaI enzyme (see Note 6). Incubate at $30^{\circ} \mathrm{C}$ for $24 \mathrm{~h}$. To stop digestion, add $1 \mathrm{~mL}$ of 0.5 M EDTA pH 8.0 to the sample and incubate for $5 \mathrm{~min}$ at room temperature $\left(20-25^{\circ} \mathrm{C}\right)$.

\subsection{Pulsed-field Gel Electrophoresis}

1. Cool 2.2 L of $0.5 \mathrm{X}$ TBE buffer to $4^{\circ} \mathrm{C}$.

2. Cool $100 \mathrm{~mL}$ of $1 \%$ agarose gel to $50^{\circ} \mathrm{C}$.

3. Place the plugs over the comb teeth, cut them just over the midpoint and stick them to the comb teeth with $0.005 \mathrm{~mL}$ of melted agarose. At this stage remember to include the plug containing the CHEF DNA size standard lambda ladder. Put the comb at $4^{\circ} \mathrm{C}$ for $10-15$ min to let the plugs adhere firmly to the comb.

4. Assemble the gel casting tray, position the comb with samples in the upper corresponding slots of the casting stand so that the height of the comb is $2 \mathrm{~mm}$ above the surface of the platform. Pour in the melted agarose and wait until it solidifies (approximately 15-30 minutes). Upon pouring, it may happen that bubbles form. They need to be removed. They 
can be either dragged to the side of the gel using a disposable pipette tip or made blow up by touching the bubble surface with a pin or a flamed wire loop if available.

5. Pour the $0.5 \mathrm{X}$ TBE buffer into the electrophoresis chamber and activate the variable speed pump at maximum speed and set the cooling module at $14^{\circ} \mathrm{C}$. Let the system reach the $14^{\circ} \mathrm{C}$ uniformly.

6. Once the gel is solidified, remove the comb and place it on the frame located in the electrophoresis chamber.

7. Set the instrument in the two-state mode with the parameters reported in Table 1 and start the run.

8. Once the program is completed, stain the agarose gel by soaking it in $300 \mathrm{~mL} \mathrm{of} \mathrm{H}_{2} \mathrm{O}$ containing $0.5 \mu \mathrm{g} / \mathrm{mL}$ ethidium bromide for $30 \mathrm{~min}$. Rinse three times with $300 \mathrm{~mL}$ tap water each time, then visualize and photograph under UV light $(254-360 \mathrm{~nm})$. A typical result obtained applying the "standard" run condition is shown in Figure 1 (see Note 7). 


\section{Notes}

1. It is opportune to measure optical density of the bacterial suspension as differences are obtained for different strains after the overnight culture. They need to be equalised to make the comparison of PFGE profiles easier and more reliable. Optical density of a typical $S$. pyogenes over-night culture is about 1-2 units $(600 \mathrm{~nm})$. Hence the bacterial suspension needs to be diluted by about 1:1 (e.g. $500 \mu \mathrm{L}$ of bacterial suspension and $500 \mu \mathrm{L}$ of broth medium) to obtain a reading below 1 unit.

2. The minimum volume of agarose gel to be prepared is $10 \mathrm{~mL}$ regardless of the number of samples.

3. In a typical bacterial suspension, equation that relates optical density (OD at a wavelength of $600 \mathrm{~nm}$ ) and colony forming units (c.f.u.) is $1 \mathrm{OD}_{600 \mathrm{~nm}} / \mathrm{mL}=1-2 \times 10^{9} \mathrm{cfu} / \mathrm{mL}$ and it corresponds to $4-10 \mu \mathrm{g}$ of chromosomal DNA/mL.

4. Discard the supernatant immediately and do not lose the pellet. Some strains may show a fluffy pellet and loss of a certain amount of cells is unavoidable. In that case, the pellet shows a visible size reduction. A partial solution is to increase the starting volume of bacterial culture so as to obtain an approximately constant pellet size for all the samples. It is also possible to prepare the bacterial suspension by starting from the bacterial colonies grown on solid medium supplemented with sheep blood, instead of resuspending a few colonies into specific broths (9). In that case, it is necessary to resuspend the colonies into TEN buffer and check the turbidity of the bacterial suspension until it reaches approximately 1.5-2 McFarland. At this time, the bacterial suspension is ready to be mixed with low melting point agarose (ratio of 1:1).

5. In order to work as fast as possible and to avoid undesired solidification of the agarose- 
cells mixture, be sure to have both the micropipettes and the vortex close to you before starting this step. Moreover, it is strongly suggested to work close to a water bath set at $50^{\circ} \mathrm{C}$ in which the melted agarose will be kept when preparing the agarose-bacterial cells mixture in order to avoid the solidification of agarose.

6. The chromosomal DNA of some strains is not susceptible to SmaI macro-restriction, undermining the possibility of analyzing and comparing these strains with other strains. The reason for the resistance to digestion is methylation of the 3' cytosine of the SmaI recognition site due to the expression of a methylase encoded by a gene carried by chimeric genetic elements (10). Two related exogenous elements have been described so far possessing the mentioned methylase, namely the bacteriophage $\Phi 10394.4$ (11) and the conjugative transposonTn1207.3 (12). Among genes harbored by these exogenous elements there are $m e f(\mathrm{~A})$ and $\operatorname{msr}(\mathrm{D})$ that are responsible for the low level resistance to 14- and 15- membered macrolides (e.g. erythromycin). Nowadays, the prevalence of mef(A)-positive erythromycin resistant $S$. pyogenes is generally low, but it used to be quite high in the past (13). Moreover, among mef(A)-positive erythromycin resistant S. pyogenes only a fraction harbor the genetic elements expressing the methylase that modifies the SmaI recognition sites. Once the presence of mef(A)-positive strains with SmaI undigested chromosomal DNA is observed, it is necessary to use alternative restriction enzymes, such as the methylation insensitive isoschizomer of SmaI, Cfr9I (14).

7. The in silico SmaI restriction analysis of $S$. pyogenes genomic DNA available in public databases gives an overview of the general features of the product of "macro-restriction". The average number of cutting sites per genome is 23 (C.I.95\%: 22-24) with a maximum of 26 (strain NZ131, ref. 15) and a minimum of 20 (strains MGAS1882 and MGAS15252, ref. 16). The average fragment size is 81,293 bp (C.I. 95\%: 78,645 - 83,941 bp) with a 
maximum at 554,983 bp (MGAS8232, ref. 17) and a minimum at 1,099 bp (NZ131). It is possible to plot the distribution of fragments resulting from the digestion with SmaI of the genomic DNA of each strain. Figure 3 shows the result of the in silico restriction analysis in a form resembling that obtainable by a real PFGE run. It is evident how banding is concentrated in the range of lengths between $20,000 \mathrm{bp}$ and 200,000 bp. Hence, a good resolution of the PFGE would be expected for fragments within that range. It is often the case of pictures reported in published papers showing a good resolution between 50,000 and 500,000 bp of fragment lengths. Bands below 50,000 bp are not shown; either because the gel is cut or the run has been set to resolve bands above that limit. This occurrence is a limitation to the possibility of resolving differences accounted for by bands $<50,000 \mathrm{bp}$. Another weak point is the unneeded search for resolving bands above 300,000 bp, in view of their paucity in the typical SmaI generated banding pattern in $S$. pyogenes. Actually there have been good examples of PFGE executions where part of this issue was eventually considered (18). If the epidemiological study requires a complete and deep discrimination between strains, the same DNA samples run with either condition \#1 or \#2 may be separated by FIGE using condition \#3 (Table 1), which gives the best resolution in the range 5,000-50,000 $\mathrm{Kb}$ (Figure 2). Results can then be combined for cluster analysis. 


\section{References}

1. Deurenberg RH, Stobberingh EE (2008). The evolution of Staphylococcus aureus. Infect Genet Evol 8:747-63.

2. Petrelli D, Repetto A, D'Ercole S, et al. (2008) Analysis of meticillin-susceptible and meticillin-resistant biofilm-forming Staphylococcus aureus from catheter infections isolated in a large Italian hospital. J Med Microbiol 57:364-372.

3. Silva-Costa C, Friães A, Ramirez M, Melo-Cristino J (2012) Differences between macrolide-resistant and -susceptible Streptococcus pyogenes: importance of clonal properties in addition to antibiotic consumption. Antimicrob Agents Chemother 56:5661-6.

4. Zampaloni C, Vitali LA, Prenna M, et al. (2002) Erythromycin resistance in italian isolates of Streptococcus pyogenes and correlations with pulsed-field gel electrophoresis analysis. Microbial Drug Resist 8:39-44.

5. Dicuonzo G, Gherardi G, Lorino G, et al. (2001) Group A streptococcal genotypes from pediatric throat isolates in Rome, Italy. J Clin Microbiol 39:1687-1690.

6. Vitali LA, D’Ercole S, Petrelli D, et al. (2009) Distribution of Phage-Associated Virulence Genes in Pharyngeal Group A Streptococcal Strains Isolated in Italy. J Clin Microbiol 47:1575-1577.

7. Beres SB, Musser JM. (2007) Contribution of exogenous genetic elements to the group A Streptococcus metagenome. PloS One 2: e800.

8. Struelens MJ (1996) Consensus guidelines for appropriate use and evaluation of microbial epidemiologic typing systems. Clin Microbiol Infect 2:2-11.

9. Beall, B., G. Gherardi, M. Lovgren, et al. (2000) emm and sof gene sequence variation 
in relation to serological typing of opacity factor positive group A streptococci. Microbiology 146:1195-1209

10. Euler CW, Ryan PA, Martin JM, Fischetti VA (2007) M.SpyI, a DNA methyltransferase encoded on a mefA chimeric element, modifies the genome of Streptococcus pyogenes. J Bacteriol 189:1044-54.

11. Banks DJ, Porcella SF, Barbian KD, et al. (2003) Structure and distribution of an unusual chimeric genetic element encoding macrolide resistance in phylogenetically diverse clones of group A Streptococcus. J Infect Dis 188:1898-908.

12. Santagati M, Iannelli F, Cascone C, et al. (2003) The Novel Conjugative Transposon Tn1207.3 Carries the Macrolide Efflux Gene mef(A) in Streptococcus pyogenes. Microbial Drug Resist 9:243-7.

13. Robinson DA, Sutcliffe JA, Tewodros W, et al. (2006) Evolution and global dissemination of macrolide-resistant group A streptococci. Antimicrob Agents Chemother 50:2903-11.

14. Carriço JA, Silva-Costa C, Melo-Cristino J, et al. (2006) Illustration of a common framework for relating multiple typing methods by application to macrolide-resistant Streptococcus pyogenes. J Clin Microbiol 44:2524-32.

15. McShan WM, Ferretti JJ, Karasawa T, et al. (2008) Genome sequence of a nephritogenic and highly transformable M49 strain of Streptococcus pyogenes. $J$ Bacteriol 190:7773-85.

16. Fittipaldi N, Beres SB, Olsen RJ, et al. (2012) Full-genome dissection of an epidemic of severe invasive disease caused by a hypervirulent, recently emerged clone of group A Streptococcus. Am J Pathol 180:1522-34. 
17. Smoot JC, Barbian KD, Van Gompel JJ, et al. (2002) Genome sequence and comparative microarray analysis of serotype M18 group A Streptococcus strains associated with acute rheumatic fever outbreaks. Proc Natl Acad Sci USA 99:4668-73.

18. Friães A, Ramirez M, Melo-Cristino J (2007) Nonoutbreak surveillance of group A streptococci causing invasive disease in Portugal identified internationally disseminated clones among members of a genetically heterogeneous population. $J$ Clin Microbiol 45:2044-7. 


\section{Figure Captions}

Figure 1. Picture of a sample PFGE gel, run applying the standard condition \#1 (Table 1).

CHEF DNA size standard lambda $48.5 \mathrm{~Kb}$ ladder is loaded onto lanes 1, 8, and 15 .

Figure 2. Picture of a PFGE gel run applying the FIGE condition \#3 (Table 1). DNA size standard $5 \mathrm{~Kb}$ ladder is loaded onto lane 9.

Figure 3. In silico generated banding pattern of chromosomal DNA sequences from genomes available in the GeneBank database. Strain names are reported along the X-axis. 
